\title{
„Knowledge is power": Studium MBA v perspektivě Bourdieuho teorie kapitálů ${ }^{1}$
}

\author{
Jana Dvořáčková
}

\author{
Masarykova univerzita, Fakulta sociálních studií, Katedra sociologie \\ Univerzita Pardubice, Filozofická fakulta, Katedra sociálních věd
}

Redakci zasláno 28. 8. 2014 / upravená verze obdržena 17. 12. 2014 / k uveřejnění přijato

18. 12.2014

\begin{abstract}
Abstrakt: Cílem této empirické studie, která vychází z ročního etnografického výzkumu na soukromé vysoké škole, je analyzovat, jaký význam má studijní program MBA v reprodukci sociálních diferencí. V první části je představeno teoretické pozadí studie, jímž jsou Bourdieuho koncepty kulturního, ekonomického, symbolického a sociálního kapitálu a jeho pojetí mechanismu sociální reprodukce skrze školské instituce. Druhá část příspěvku přibližuje klíčové rysy soukromé vysoké školy, kde se výzkum realizoval. Třetí část je věnována analýze manifestních cílů MBA programu, jímž je posílit kulturní a ekonomický kapitál studujících - rozvíjet jejich znalosti, kariérní perspektivy i úspěchy v podnikání. Vedle toho se zabývá MBA studiem coby zdrojem symbolického i sociálního kapitálu. Jak text ukazuje, MBA program je vedle prostředku získávání znalostí a dovedností současně prostorem konverze ekonomického kapitálu do kapitálu symbolického a sociálního. Ty následně zvyšují objem ekonomického kapitálu studujících, čímž dále upevňují jejich sociální pozici.
\end{abstract}

Klíčová slova: MBA, Bourdieu, sociální reprodukce, symbolický kapitál, sociální kapitál, ekonomický kapitál, kulturní kapitál

„Titul MBA znamená lepší místo a více peněz.“ „Váš klíč ke kariéře.“ „Prestižní manažerské studium.“ „Studium zaměřené na praxi.“ Již první hesla, která po zadání zkratky MBA (Master of Business Administration) nabídne internetový vyhledávač, prozrazují, že hodnotové napřažení studijních programů MBA zdaleka nespočívá pouze ve vzdělávacích cílech. Slogany, z nichž většina pochází z webových stránek škol, které tyto manažerské programy nabízejí, chtějí aktivně komunikovat zejména to, že absolvování studia je cestou k osobnímu úspěchu a postupu na kariérním žebříčku. Studium nese obecně

1 Tento text vznikl v rámci projektu Masové vysoké školství v institucionálním kontextu: etnografie vysokoškolských kateder v České republice podpořeného Grantovou agenturou České republiky (GAČR P404/11/0127, 2011-2013).

DOI: $10.5817 /$ PedOr2015-1-84 
přídech něčeho mimořádně prestižního, čemuž odpovídají i ceny, které se za něj průměrně platí. Výše školného v ČR zpravidla přesahuje částku dvou set tisíc, výjimečná však není ani dvojnásobná či dokonce trojnásobná suma.

Historie MBA programů sahá do počátku 20. století, kdy se tyto programy etablovaly v USA. Koncem 50 . let se daný model studia rozšíril do Evropy, zejména Velké Británie (History of the MBA, 2012; The MBA - Some history, 2003). Do ČR proniká v období transformace a rozvíjí se mimo univerzitní systém. Programy MBA byly původně zaštit'ovány zahraničními institucemi. I dnes jsou velmi běžně provozovány na bázi franšízingu, kdy je jejich obsah určován zahraniční mateřskou školou. Dalším akreditačním modelem jsou tzv. validace, které však ponechávají místním školám větší svobodu při utváření kurikul a kurzů. Validující instituce následně dohlíží na dodržování standardů řízení kvality (Šmikmátor, 2013, s. 12). Vedle toho se v českém prostředí, podobně jako v jiných zemích, postupně ustavily národní asociace s akreditační pravomocí (Česká asociace MBA škol, Asociace institucí manažerského vzdělávání). Ač ve většině zemí MBA programy formálně nespadají do kategorie vysokoškolského vzdělávání, přetrvává tendence definovat toto studium jako studium odpovídající magisterské úrovni. V souladu s tím je i zpravidla uplatňovaný požadavek předchozího bakalářského studia a jednoletá až dvouletá délka studia (Malý, 2014).

Bývají-li MBA programy řazeny spíše mezi programy rozvíjející profesní kvalifikaci, především $\mathrm{z}$ počátku představovalo $\mathrm{v}$ ČR MBA studium, jak uvádějí Locke a Schöne (2004, s. 191), i určitý prostředek rekvalifikace. Nabízelo možnost doplnění poznatků z oblastí managementu či marketingu, které poskytovalo socialistické školství pouze v omezené míře. Tomu podle nich odpovídal také poměrně vyšší věkový průměr studujících. Ani v tomto případě však, jak se pokusím ukázat v následujícím textu, nepoháněl poptávku po daném studiu jednoduše znalostní deficit. Jiné motivy a př́nosy studia pak dnes vynikají o to více, kdy jsou vzdělávací obsahy, které MBA programy poskytují, studujícím v principu dobře dostupné i mimo rámec těchto finančně velmi náročných kurzů. Cílem zde ovšem není tvrdit, že studium MBA je ve svých mimovzdělávacích příslibech a dopadech něčím zcela výjimečným a odlišným od jiných vzdělávacích programů. Naopak vycházím z perspektiv, které zviditelňují mimovzdělávací mechanismy spojené s institucí školy obecně a zdůrazňují její roli v reprodukci sociálních a kulturních diferencí (přehled těchto teorií viz např. Katrňák, 2004; Simonová, 2011; Veselý \& Matějů, 2010). Především pak čerpám z Bourdieuho poznatků o vzdělávacím systému coby prostředku reprodukce a posilování různých forem 
kapitálů (Bourdieu, 1996; Bourdieu \& Passeron, 1990). V následné analýze se soustřed'uji na konkrétní podoby, jichž mimovzdělávací motivy, přínosy či dopady v prŕípadě MBA studia nabývají, a na mechanismy, které v tomto ohledu rozehrávají jak samotní aktéři, tak i poskytovatelé MBA programu.

Tyto procesy nahlížím skrze případ soukromé školy, kterou jsem měla možnost v letech 2011-2013 zkoumat (za přispění dalších členek výzkumného týmu) v rámci obecněji zaměřeného projektu Masové vysoké školství $v$ institucionálním kontextu: etnografie vysokoškolských kateder v České republice (Filozofická fakulta Univerzity Pardubice, Sociologický ústav AV ČR a Centrum pro studium vysokého školství). Klíčovou charakteristikou etnografického výzkumu je dlouhodobý pobyt výzkumníků v prostředí, které je předmětem jejich zájmu. Jeho hlavní metodou je zúčastněné pozorování. Mimo pozorování ve výuce, při zkoušení, na poradách či méně formálních akcích škol jsme v rámci terénního výzkumu, který se vedle soukromé školy realizoval na čtyřech katedrách veřejných vysokých škol, uskutečnili množství polostrukturovaných rozhovorů s vyučujícími, studujícími, administrativními pracovnicemi a pracovníky i vedeními škol. Provedli jsme také analýzu vybraných dokumentů (webových stránek kateder, výukových materiálů, strategických dokumentů, zápisů ze schůzek, životopisů vyučujících apod.).

Jakkoli etnograficky koncipovaný výzkum neumožňuje snadná zobecnění, jeho výhodou je možnost zachytit přediva vztahů a procesů v jejich komplexnosti. Dlouhodobý pobyt ve zkoumaném prostředí poskytuje jedinečný způsob, jak proniknout k rovinám reality, které se dopředu nemusejí zdát podstatné a které mnohdy nepovažují za zajímavé nebo hodné zmínění ani studovaní aktéři. Teprve vlivem pozorování se často ozřejmuje ve větším detailu, kudy výzkumné kroky směřovat a na co přesně svou pozornost zaměřit (Davies, 2008, s. 81; Gobo, 2008, s. 5). Dlouhodobost pobytu také umožnila vstup do méně formálních rovin skutečnosti. V neposlední řadě pak poskytla i důležité pozadí pro interpretaci perspektiv, skrze něž různě situovaní aktéři zvýznamňují jednotlivé procesy a situace, jichž jsou součástí.

\section{Vzdělávací systém jako prostředí reprodukce nerovností}

Přestože se o vzdělávání často uvažuje jako o nástroji, který jedincům umožňuje překonávat omezení spjatá s jejich sociálním původem, jelikož zhodnocuje a tř́dí jedince na základě jejich individuálního talentu a píle, empirické 
výzkumy opakovaně ukazují, že instituce školy napomáhá skrze řadu mechanismů reprodukovat existující třídní, genderové či etnické nerovnosti (Oakes, 1985; Shavit \& Blossfeld, 1993; Shavit \& Müller, 1998; v českém prostředí např. Jarkovská \& Lišková, 2008; Jarkovská, Lišková, \& Šmídová, 2010; Katrňák, 2004; Matějů, Straková, \& Veselý, 2010; Nekorjak, Souralová, \& Vomastková, 2011). Téma sociální a kulturní reprodukce v sociologii vzdělávání výrazně ožívá v 60. a 70. letech (např. Bernstein, 1975; Bowles \& Gintis, 1976; Collins, 1979; Willis, 1977). Jedno z bezesporu nejvýraznějších výkladových schémat, jehož prostřednictvím můžeme porozumět roli instituce školy v reprodukci sociálních diferencí, však představil ve svých dílech právě sociolog Pierre Bourdieu, částečně ve spolupráci s JeanemClaudem Passeronem (Bourdieu, 1988, 1996, 1998; Bourdieu \& Passeron, 1964, 1990).

V Bourdieuho myšlenkovém schématu (Bourdieu, 1996, 1998) je společenské postavení jedinců $\mathrm{v}$ moderních společnostech zejména odrazem jimi vlastněného ekonomického a kulturního kapitálu a jejich poměru. Tyto kapitály strukturují sociální prostor, kde jedincům, dle jejich různého obdaření kapitály, přináleží diferencované pozice. Zatímco ekonomický kapitál se odvozuje od výše materiálních statků, jimiž aktéři disponují, kulturní kapitál vyjadřuje jejich myšlenkové dispozice. Ty úzce souvisejí s typem socializace a druhem získaného vzdělání. Vedle těchto druhů kapitálu však autor rozlišuje například také sociální kapitál, jenž odráží postavení jedince ve vztahových sítích a jeho status. Důležitou vlastností sociálního kapitálu je jeho proměnitelnost v jiné typy kapitálů. ${ }^{2}$ Dále pak vymezuje kapitál symbolický, jímž se podle něho může stát kterákoli vlastnost, pokud je v dané společnosti definována a vnímána jako něco, co si zasluhuje uznání či úctu. Značnou moc distribuovat symbolický kapitál má stát jakožto instance udělující tituly a hodnosti (Bourdieu, 1998, s. 81).

\footnotetext{
Jistá míra konvertability je však spojena i s dalšími kapitály. Relativní hodnota různých druhů kapitálu není plně stabilní. Mezi aktéry a institucemi disponujícími takovým množstvím určitého z kapitálů, které jim poskytuje dominantní postavení, se rozprostírá pole moci, kde je podoba směnného kurzu mezi kapitály předmětem vyjednávání či soupeření, a to např́ílad prostřednictvím obrany či kritiky oprávněnosti toho kterého z kapitálů coby podloží vládnutí. Jednou z podstatných změn, která ovlivnila dominantní mody reprodukce, byl např́klad historický nárůst relativní důležitosti akademických titulů. Poměry v definicích legitimních základů vládnutí následně ovlivňují i reprodukční strategie aktérů, jejichž prostřednictvím si snaží udržet pozice v sociálním prostoru (Bourdieu, 1996, s. 277).
} 
K odlišnému postavení ve společenském prostoru strukturovaném primárně objemem a vzájemným poměrem ekonomického a kulturního kapitálu, jímž jedinci disponují, se váží diferencované životní styly, druhy postojů, orientací a zálib osvojované v průběhu socializace (habitus). Školské instituce (všech stupňů) se pak podílejí na reprodukci struktury sociálního prostoru, jelikož pomáhají předávat společenskou dělbu kulturního kapitálu. Přispívají k přenosu kulturního kapitálu tím, že oceňují právě ty hodnoty a schopnosti, kterými disponují jedinci pocházející z prostředí s jeho vyšším objemem. Jakkoli je kulturní kapitál získanou vlastností, jeví se, jak zdůrazňuje také Wacquant (1996, s. x), jako osobní rys svého nositele. Na poli vzdělávacích institucí bývá vnímán jako důsledek nadání či úsilí, je oceňován coby individuální úspěch.

Vzdělávací systém tedy umocňuje rozdílnost kulturních orientací osvojených jedinci z různých sociálních pozic $\mathrm{v}$ rámci raných fází jejich života. Funguje podle Bourdieuho jako „ohromný kognitivní stroj, který neustále redistribuuje studující, jež jsou podrobeni jeho drobnohledu, dle jejich předchozích pozic v systému distribuce" (1996, s. 1). Zneviditelněny jsou tak i strategie rodin, které v zájmu udržení vlastní sociální pozice vědomě či nevědomě dlouhodobě investují do vzdělání potomků, at' už materiálně nebo prostřednictvím podpory určitých typů aktivit. Jejich investice bývají zpravidla o to významnější, čím je vyšší objem jimi vlastněného kulturního kapitálu a čím je větší jeho poměr vůči jejich ekonomickému kapitálu (Bourdieu, 1998, s. 27). Redistribuce žáků a studujících v kontextu školy se uskutečňuje např́íklad skrze percepční a třídící operace ze strany vyučujících. Tím škola zároveň napomáhá jejich rozdělení do různých typů škol. Rozdílné školy přitahují a oceňují studující s odlišnými habituálními dispozicemi. Hierarchie mezi různými akademickými institucemi či obory jsou systematicky propojeny s hierarchiemi v sociálním prostoru, odlišné typy škol seskupují jedince z rozdílných (avšak vzájemně př́buzných) souřadnic v něm. Utvářejí hranice mezi různými skupinami, reprodukují výchozí dispozice prostřednictvím kultivace určitých vidění světa a posilování odlišností mezi styly práce. Studující se na tomto mechanismu podílejí např́íklad prostřednictvím habitu odpovídajícím výběrem studijních disciplín a předmětů (Bourdieu, 1996, s. 159).

Úspěch $\mathrm{v}$ postupu $\mathrm{v}$ rámci vzdělávacího systému a školských hierarchií je vlivem nastíněných mechanismů chápán jako legitimní forma výběru. Institucionalizovaný kulturní kapitál má současně efekt symbolického kapitálu - poskytuje prestiž i uznání specifické způsobilosti rozumět realitě, jež 
hrají důležitou roli v procesech vládnutí a legitimizace moci. Zejména vysokoškolské tituly, o to více pak tituly z prestižních škol, fungují jako „posvěcení práva vládnout". Nastolují mezi lidmi - těmi, kdo tituly vlastní a nevlastní, jakož i mezi nositeli různých titulů - diference, jejichž garantem je (obvykle) stát. Vzdělávací instituce tedy podle Bourdieuho $(1996,1998)$ třídí jedince v souladu s jejich sociálním původem a výsledky svých třídících operací posvěcují. Hranice - percepce odlišnosti a oddělenosti - se vepisují jak do obecného povědomí, tak do nositelů titulů samotných. V tomto smyslu je vzdělání v moderních společnostech, jakkoli se prezentuje jako důsledek talentu a úsilí, podstatným základem dominance a její legitimizace.

Situaci v ČR charakterizuje právě vysoká míra intergenerační vzdělanostní reprodukce, pozorována byla vysoká závislost dosaženého vzdělání jedince na vzdělání a socioekonomickém postavení rodičů (Simonová, 2011, s. 11). Vzdělanostní kapitál je zde zároveň výrazným stratifikačním činitelem: výzkumy poukazují na poměrně silný vztah mezi dosaženým vzděláním na straně jedné a zaměstnaností, vykonávaným zaměstnáním a výší příjmu na straně druhé (Matějů, Straková, \& Veselý, 2010, s. 13). V př́́padě MBA titulů je nicméně situace $\mathrm{v}$ ČR specifická v tom smyslu, že namísto státu jsou jejich garanty zahraniční univerzity či jiné instituce, přičemž skrze dosavadní odmítání nostrifikace diplomů stát garanci těmto programům fakticky upírá. Přestože však kapitál tímto studiem budovaný zcela nezapadá do úzké definice vzdělanostního kapitálu, je MBA titul - zvláště v relevantních profesních kruzích - coby mj. doklad kulturního kapitálu poměrně široce přijímán. Těší se prestiži, která současně souvisí s jeho „západním původem“ a čerpá také z exkluzivního postavení skupin, které jím disponují (či v minulosti disponovaly). $\mathrm{V}$ podmínkách masifikace vysokoškolského studia, kdy tradiční tituly plní stále méně svou diferenciační funkci, může tento titul pro některé představovat vítanou formu odlišení či sebeselekce.

\section{Základní charakteristiky zkoumané instituce}

Škola, jejíž MBA programy jsem měla možnost v rámci prováděného etnografického výzkumu navštěvovat, je metropolitní soukromou školou. Má poměrně vysoký objem studujících, jelikož mimo MBA programy nabízí také řadu dalších studijních programů. Jedná se o školu s relativně dlouhou historií, v zájmu udržení její anonymity se zde však soustředím pouze na detaily, které jsou relevantní z hlediska následné analýzy. MBA programy, které jsou 
na škole vnímány coby oblast její hlavní profilace, jsou provozovány ve spolupráci se zahraniční univerzitou, což škole umožňuje udělovat jí certifikované diplomy. Programy podléhají požadavkům na řízení kvality ze strany tohoto zahraničního partnera, jejich koncepce vzniká v součinnosti s ním a vzdělávací proces podléhá jeho kontrole. První MBA program se původně realizoval současně také pod institucionálním zastřešením jedné z veřejných vysokých škol. Lektorský sbor tvořili především vyučující této školy. Později byl tento program převeden na nově vzniklou soukromou školu (akciovou společnost). Spolu s tím na dané soukromé škole začala působit i část vyučujících, kteří s ním byli spjati za původního uspořádání (rozhovory, květen 2012 - únor 2013). V současné době škola spolupracuje i s další veřejnou vysokou školou. Na veřejných vysokých školách paralelně vyučuje také řada jejích dalších vyučujících. Pedagogický sbor MBA programů dále doplňují odborníci a odbornice z praxe.

\section{$3 \quad$ MBA program jako prostředek sociální reprodukce}

\subsection{Manifestní cíle: posilování kulturního a ekonomického kapitálu}

Definice vzdělávacích cílů a profilu absolventa, které předkládají letáky školy a slogany na jejích webových stránkách, většinou na prvním místě akcentují rozšiřování znalostí managementu a kvalitu poskytovaného studia. Škola také vyzdvihuje vysoký podíl vysokoškolských vyučujících v lektorském týmu, čímž podtrhuje akademickou hodnotu programu. ${ }^{3}$ Silný důraz je však zároveň kladen na rozvoj praktických poznatků a jejich zprostředkování odborníky z praxe, což škole umožňuje vymezit se vůči vzdělávacím programům veřejných vysokých škol.

Jak uvádějí Locke a Schöne (2004, s. 191), role MBA programů v doplňování znalostního deficitu představovala důležitý motiv studia v období politické a ekonomické transformace, kdy se ekonomické vzdělání získané v socialistické éře stalo zastaralým (na což, lze předpokládat, veřejné vysoké školství nemohlo reagovat dostatečně flexibilně). Bourdieu (1998, s. 23) zároveň na př́kladu socialistického Německa ukazuje, a tuto perspektivu

\footnotetext{
Přestože se s programy soukromých škol stereotypně pojí představa jejich odlišné kvality od programů škol veřejných, je pravděpodobné, že přinejmenším z hlediska vzdělávacích obsahů existuje mezi oběma typy škol poměrně silný průnik. Ten je důsledkem faktu, že řada vyučujících působí na soukromých a veřejných školách paralelně, přičemž zde vyučuje obdobně zaměřené kurzy (viz Dvořáčková, 2013, s. 11).
} 
lze bezpochyby uplatnit i v případě Československa, že sociální prostor nemusí být $\mathrm{v}$ různých společnostech nutně či dominantně diferencován podle ekonomického a kulturního kapitálu. V NDR podle něho sehrával důležitou diferenciační funkci politický kapitál, který poskytoval přístup ke statkům a službám, zatímco role ekonomického kapitálu byla oslabena. Polistopadové proměny principů diferencujících sociální prostor, tedy pokles významu politického kapitálu a nárůst role ekonomického, nepochybně iniciovaly také procesy konverze kapitálů coby strategie udržení pozic. Z této perspektivy mohlo studium poskytovat i jistou legitimitu ekonomickému vládnutí. ${ }^{4}$

Vyučující promítá na powerpointu snímek, který je nadepsán „Knowledge is power“. Říká, že toto heslo slyšel na nějakém školení a že ho tehdy zasáhlo. „Vědění vám dává sílu i tu vnitřní vyrovnanost. Sílu vnitřního klidu. Schopnost se neemotivně rozhodovat, v klidu a koncepčně." Dále parafrázuje zbylé řádky snímku: „Power vždycky vede $\mathrm{k}$ action. A action je competitive advantage. Na začátku je vždy ale ta knowledge. A to je to MBA. To MBA by vás v tom mělo posunout." (terénní deník, červen 2012)

Na druhém místě propagační materiály školy vyzdvihují přínos programů pro kariérní růst absolventů - potenciál přetavení vědění a dovedností, jak naznačuje i výše uvedená citace z hodiny, do ekonomického kapitálu. Citovaný vyučující dále dodal: „Každý chce vydělávat peníze. Nikdy nevěřte tomu, když někdo ř́ká, že chce na prvním místě zaměstnat lidi, pozvednout komunitu, zlepšit bezpečnost zaměstnancủ. Ta kasa na konci musí cinknout" (terénní deník, červen 2012). Jeden z dokumentů, který byl součástí složky distribuované na dni otevřených dveří, také explicitně pojmenovává úspěšné absolventy jako někoho schopného vytvářet (což se uvádí na prvním místě) „materiální hodnoty". V těchto výrocích je tedy patrná jistá ekonomizace vzdělání. Na ekonomický kapitál škola na některých místech apeluje i skrze přísliby facilitace rozvoje firem, kde studující působí. At’ už skrze propagační materiály či rétorické přisuzování pozice v rámci výuky se ke studujícím obrací jakožto $\mathrm{k}$ majitelům či hlavám podniků a prezentuje studium coby př́nos $\mathrm{k}$ dalšímu rozvoji podnikání nebo cestu ke zvládnutí recese. Vyučující jsou také někdy označováni za potenciální konzultanty, kteří mohou studujícím napomoci řešit problémy jejich firem (webové stránky; terénní deník, červen 2012).

4 Pozoruhodným je v tomto kontextu i zjištění Lockeho a Schöna (2004, s. 191), kteří parafrázují výpověd' jednoho z českých lektorů MBA programů, podle níž byla v porevolučních studijních skupinách vysoká koncentrace bývalých vysokých komunistických funkcionářu. 
Podle Bourdieuho (1996, s. 276) obecně závisí potenciál návratu investic do vzdělání na struktuře vlastněného kapitálu, poměru mezi ekonomickým a kulturním kapitálem. Pro udržení a reprodukci sociální pozice u držitelů s vysokým podílem ekonomického kapitálu nejsou investice do kulturního kapitálu klíčové. Na druhou stranu Bourdieu hovoří o proběhlé historické změně ovlivňující dominantní způsoby reprodukce sociálních pozic - o nárůstu relativní důležitosti akademických titulů. Studium MBA se z této perspektivy prezentuje současně jako cesta k posílení kulturního i ekonomického kapitálu. Zároveň představuje, vzhledem k výši školného, které funguje jako bariéra, separátní kolej pro reprodukci ekonomické elity. (Vyšší průměrný věk studujících nicméně vytváří prostor pro nabytí vstupního ekonomického kapitálu ne zcela v závislosti na výchozím rodinném postavení, jakkoli mají životní strategie tendence odrážet habitus.) Požadovaná částka za školné, která je údajně v případě studované školy spíše nadprůměrná, je prezentována jako určitá záruka kvality, doklad toho, že se nešetří v oblasti akreditací, tedy kvality zahraničních garantů, jimž se platí poplatky, na lektorském týmu apod. (rozhovor s pracovnicí marketingového oddělení, listopad 2012). ${ }^{5}$ Pracovník vedení (rozhovor, listopad 2011) nicméně reflektoval propojení výší školného a spatřované prestiže programu, roli těchto úvah při nastavování ceny MBA programů.

Sama schopnost zaplatit částku za školné obdařuje studující jistou dávkou prestiže, jelikož dokládá jejich vysoký ekonomický status nebo jejich výjimečnou hodnotu pro některého ze zaměstnavatelů, kterému za tuto nemalou investici stojí. Na druhou stranu však MBA programy naráží na problém kvalifikovat se coby šířeji přijímaný doklad kulturního kapitálu. Ve veřejném povědomí MBA titul mnohdy figuruje, jak si postěžoval na webových stránkách školy jeden $\mathrm{z}$ absolventů, jako „pouze osvědčení o absolvování drahého studia“. Jak zástupci školy, tak i další nositelé titulu v poskytnutých referencích, se proto snaží spatřovanou nízkou hodnotu studia pozitivně přeznačit a redefinovat prostřednictvím toho vztahy na mocenském poli. Činí tak mnohdy prostřednictvím devalvace veřejných vysokých škol coby tradičních poskytovatelů institucionalizovaného kulturního kapitálu. Jimi předávané

Souvislost výše školného s typem (či „kvalitou“) akreditující instituce je zdůrazňována zejména proto, že na poli s MBA programy dnes působí řada společností, které jsou akreditovány ne zcela důvěryhodnými zahraničními organizacemi. Ty např́klad nemusejí mít patřičné oprávnění ke garanci těchto programů nebo dostatečně nedohlížejí na kvalitu garantovaných programů. Dané společnosti poskytují absolventům zdánlivě stejný titul, avšak studium je zpravidla výrazně levnější a také méně náročné (Otevřený dopis..., 2013). 
vzdělávání kritizují pro jeho př́lišnou teoretičnost a nedostatečnou vazbu na praxi. U MBA studia naopak vyzdvihují adekvátní propojení s praxí (projev rektora 2009; reference absolventů na webu školy). V zájmu potvrzení této „adekvátnosti“ byla ze strany některých zástupců školy mobilizována protržní argumentace, v níž je zákaznický vztah mezi studujícími a školou zárukou vyšší kvality (v opozici proti neplacenému veřejnému vysokému školství), jelikož platící studující kvalitu aktivněji vyžadují a kontrolují. V logice naturalizující tržní výběr kvalitu zaručuje taktéž fakt konkurence v daném segmentu (projev rektora 2009; rozhovor s vedoucími pracovníky, listopad 2011 a květen 2012).

Jak ukazují také zahraniční diskuze, manažerské studijní programy čelí již po několik desetiletí dvojímu tlaku. Ze strany tradičních vzdělávacích institucí jsou kritizovány za nedostatečnou vědeckost, zatímco v podnikatelské sféře, poli definovaném především důrazem na ekonomický kapitál, jim bývá vytýkána př́lišná akademičnost vedoucí ke vzdalování se skutečným potřebám a aktuálním trendům sféry byznysu (např. Robbins, 1993, s. 156). Prvek souboje o hodnotu předávaného kapitálu lze pak spatřovat i v averzi některých zástupců školy vůči označování MBA programů za programy poskytující „profesní kvalifikaci“. Přestože je u programu na jednu stranu jeho napojení na profesní praxi vyzdvihováno, jeho rámování jako prostředku získání profesní kvalifikace $\mathrm{v}$ očích zástupců školy př́lišně snižuje akademickou hodnotu poskytovaného studia a staví překážky možné budoucí nostrifikovatelnosti titulů (terénní deník, červen 2012). Mimo jiné z důvodů posílení legitimity a akademické prestiže se vedení školy rozhodlo $\mathrm{v}$ minulých letech ucházet o akreditaci některých dalších poskytovaných programů ze strany Ministerstva školství, mládeže a tělovýchovy, $\mathrm{k}$ jejímuž udělení se váže i získání právního statusu vysoké školy (rozhovor s vedoucí pracovnicí, listopad 2011).

\subsection{MBA studium jako zdroj symbolického kapitálu}

Vedle manifestních cílů programu MBA, mezi něž náleží zejména budování znalostí a schopností, které mají studujícím umožnit kariérní růst a rozvíjení vlastního (především) ekonomického kapitálu, se škola zřetelně podílí na budování pověsti MBA coby titulu mimořádné prestiže. Pro určité společenské skupiny je tento titul „symbolem úspěchu“, jak ho pojmenoval jeden z bývalých studujících (rozhovor, únor 2012). Částečně pramení tato prestiž již z výše školného dokládající ekonomický status nositele MBA titulu či jeho hodnotu pro zaměstnavatele, který studium financoval. Podle jednoho 
z vyučujících některé firmy i z tohoto důvodu nositele či nositelky titulu MBA při náboru preferují (rozhovor, ř́jen 2012).

Prestiž studia a titulu je budována i skrze vyzdvihování obzvláštní přínosnosti poskytovaného vzdělání. $V$ průběhu výzkumu jsem měla například několikrát možnost zaslechnout „nadhodnocování“ MBA studia jako úrovňového mezistupně mezi studiem magisterským a doktorským (rozhovor s pracovnicí studijního oddělení, listopad 2012). Jeden z vyučujících hovořil o modelu studia, k němuž se program hlásí, jako o „alfa modelu“ (terénní deník, listopad 2012), jiný budoval výlučnost studia a těch, kdo ho absolvují, tak, že o absolventech hovořil na hodině jako o ,jedničkách“: „Vy, když budete mít to MBA, $\mathrm{z}$ vás se stanou ty jedničky. Vás se lidé budou bát. $V$ průměrných firmách $\mathrm{z}$ vás budou mít strach. Musíte si hledat ty špičkové firmy, které vás posunou dál, ne nějaké zahnívající organizace." Př́itomná pracovnice dále dodala, že podle rektora se absolventům bohužel také někdy stává, že jim na pracovišti ostatní lidé nerozumějí, čímž ale jejich výlučnost ještě posílila (terénní deník, červen 2012). Škola tak prostřednictvím těchto operací systematicky pracuje na vytváření diference mezi svými absolventy a absolventy jiných škol či ostatními lidmi. Podobně jako jiné prestižní tituly či hodnosti zprostředkovává svým nositelům symbolický kapitál, vytváří sociální hranice. Produkuje skupiny, které se vnímají jako odlišné a jsou tak vnímány rovněž okolím (srov. Bourdieu 1996, s. 79, 1998, s. 28).

Ačkoli se zdá, že tato odlišnost nositelů MBA titulu není všeobecně vnímána jako legitimní, jelikož je titulu upírána hodnota kulturního kapitálu a nese v určitých skupinách konotace koupeného statusu, jeho prestiž jsem měla možnost opakovaně zakoušet již skrze obdivné reakce okolí ohledně oblasti svého výzkumu. 0 hodnotě titulu, která se nevyčerpává hodnotou akademické kvalifikace, vypovídá i to, že řada studujících vstupujících do programu již vlastní magisterský, inženýrský či dokonce doktorský titul. To, že specifická hodnota programu nevyplývá ani z obsahů či kvalit poskytovaného vzdělávání, ostatně potvrzují také pracovníci školy, kteří dosvědčují, že z hlediska obsahu se MBA studium takřka kryje s jiným (avšak daleko levnějším) nabízeným programem. Mezi studujícími tohoto programu však již osoby s vyššími než bakalářskými tituly zpravidla nenalezneme (rozhovor s vyučujícím, květen 2012; rozhovor s pracovnicí studijního oddělení, listopad 2012).

Jak se vyjádřila i pracovnice marketingového oddělení, titul MBA je atraktivní „značkou“, která přitahuje studující téměř bez ohledu na poskytované vědění 
(rozhovor, listopad 2012). Prestiž MBA škola mimo výše uvedené rozehrává i prostřednictvím mnohem subtilnějších způsobů. Výrazná je například práce na symbolickém propojení se zemí, kde sídlí instituce poskytující škole oprávnění k provozování programu. „Západnost“ této země dodává škole na světovosti a navyšuje tak prestiž studia. Na zdech učeben visí fotografie města, kde zahraniční univerzita sídlí. Na webových stránkách školy se lze také dočíst, že absolventi/ky získávají stejný diplom, jako kdyby studovali/y přímo v zahraničí. Škola se současně odvolává na teoretické zakotvení programu v klíčových „západních teoriích“ z dané oblasti. „Dělání světovosti“ je patrné i v tom, že přestože výuka probíhá v češtině, názvy všech kurzů jsou v angličtině. Anglicky jsou nadepsány i poskytované studijní materiály. Někteří vyučující si pak připravují v angličtině také své powerpointové prezentace, což je, jak vyplynulo z promluvy jednoho z lektorů, požadováno nadřízenými.

Vedle akcentace prestiže akreditující instituce, o jejímž umístění v mezinárodních žebříčcích kvality se obšírně pojednává na jejích internetových stránkách, škola v zájmu navyšování kreditu mobilizuje i další spojence. Těmi jsou jak vybrané veřejné vysoké školy, s nimiž spolupracuje a které jí umožňují posílit svou pozici coby distributora kulturního kapitálu, tak i významné komerční subjekty (na dni otevřených dveří se např́klad rozdávala složka obsahující mj. přehled klientů znělých jmen). Za spojence dodávající prestiž je možno považovat i poměrně luxusní restaurace, kam studijní skupiny docházejí na společné obědy. Symbolická práce se stravovacími praktikami coby vnějšími atributy spojenými se sociálními pozicemi je ostatně patrná i ve složení občerstvení, které škola studujícím během výuky nabízí (luxusnější ovoce, sladké pečivo „západního střihu“ apod.) a které se v tomto smyslu zásadně odlišuje od občerstvení nabízeného studujícím jiných studijních programů. Mezi další vnější statusové symboly náleží i výrazně formální oblečení vyučujících. Na jedné z hodin, která probíhala zkraje léta, kdy teploty dosahovaly tropických hodnot, jsem měla např́klad možnost sledovat, jak si vyučující s velkými omluvami sundává sako, přestože jeho oděv (košile, vestička, kravata) byl i bez něho více než formální (terénní deník, červen 2012). Většina studujících se nicméně s takto nastavenými pravidly úpravy vzhledu plně neztotožňuje a přichází na hodiny oblečena výrazněji méně formálně.

Během výuky jsem měla poměrně často možnost sledovat vlastní situování vyučujících do pozic mocných, jakož i budování obdobných pocitů u studujících. Vyučující se například někdy vztahovali familiérním způsobem ke známým podnikatelům, což sugerovalo dojem vzájemných blízkých vazeb. 
Do významných řídících pozic se silnou možností ovlivňovat práci jiných byli, jakkoli to nutně neodpovídá jejich profilu, v rámci hodin často stavěni i studující: „Jak měníte vaše lidi?“ „Šiřte vizi a získávejte stoupence." (terénní deník, únor 2012) Ve studujících byla zároveň místy budována i hegemonní manažerská pozice. Jeden z vyučujících například používal obraty jako „tak si koupili Portugalce“ nebo výraz ,jezerák“ pro pracovníka v oblasti zemědělství (terénní deník, březen 2012). Prostřednictvím prosazovaných hodnot a konkrétních př́kladů z praxe udávaných vyučujícími na hodinách (často se jednalo o luxusní automobily a motorky) pak získávala tato manažerská pozice výrazně maskulinní obrysy. Na stereotypně maskulinní charakteristiky vetkané do MBA programů a $\mathrm{v}$ jejich rámci oceňované upozorňuje také Sinclair (1995).

Jak ukazuje Bourdieu (1996, s. 83) na příkladu francouzských grandes écoles, elitní školy mění skrze řadu praktik sebepojetí svých studentů i jejich pojetí jiných. Vzhledem k performativním účinkům tyto akty přibližují studující svému obrazu, posilují reálné diference. Studující si osvojují určité „zvyky a způsoby vystupování, typické výrazy školního slangu (kondenzované z krystalizovaných hodnot), sdílené obraty, specifický druh humoru, charakteristické způsoby pohybu, mluvy, smíchu a vystupování vůči ostatním". Utvářejí si mínění o sobě samých, které předznamenává jejich budoucí pozice. Ačkoli se samozřejmě kulturní kontext grandes écoles a jejich postavení ve vzdělávacím poli od programů MBA zásadně liší, také poskytovatelům MBA se podařilo kolem tohoto studia vybudovat určitou „elitní auru“, která probouzí obdobné performativní akty. Sturdy etal. (2006, s. 850-852) hovořív kontextu MBA studia o „identitní práci“ coby jeho nedílné součásti. V jejím důsledku se podle nich u studujících posiluje sebedůvěra či pojetí sebe sama jako strategicky uvažující bytosti. Záblesky těchto dlouhodobých procesů jsem měla možnost pozorovat v neformálních konverzacích, kdy se například studující hravým způsobem situovali mezi mocné a vtipkovali mezi sebou: „Máš pro mě nějakou dobrou nabídku? Dostanu limuzínu s řidičem?“ Jiný student si spolužákům postěžoval, že v daný den je výuka "dobrá tak pro bakaláře“, pročež se s nimi rozloučil slovy „mizím na golf“" (terénní deník, březen 2012).

Jsou to právě hodnoty, k jejichž osvojení jsou studující MBA programů vedeni, což je nezř́ídka zdrojem kritiky. Například Vaara a Faÿ $(2011$, s. 32) těmto programům vytýkají, že utvářejí specifickou třídu byznysmenů s instrumentálním a etnocentrickým přístupem ke světu. Podle Graye (2002, s. 502) MBA programy často předkládají naturalizovaný obraz tržních vztahů a manažerské dominance, prezentují je jako normální a přirozenou organizaci 
společnosti. Gray problematizuje zdánlivou neutralitu tohoto vidění, socializaci k hodnotám „turbo-kapitalismu“ i jejich legitimizaci a volá po tom, aby byly v manažerském vzdělávání uplatněny kritické př́ístupy.

Podle některých vyučujících existuje současně tendence k sítování absolventů MBA programů, aniž by je nutně pojila předchozí osobní známost, k utváření vzájemně výhodných spojenectví „vyvolených“: „Manažeři, kteří mají MBA, se už podle toho poznávají a orientují. Preferují lidi s MBA“ (rozhovor s vyučujícím, ř́ijen 2012). „Jedničky si k sobě hledají jedničky“ (terénní deník, červen 2012). Jak uvádí Bourdieu (1996, s. 79), symbolické zisky z prestižního vzdělání plynou ze dvou procesů: „každý z členů skupiny, krom toho, že se podílí na kapitálu kolektivně vlastněném a koncentrovaném v titulu, se též podílí, v logice, která je skutečně logikou magického spolupodílnictví, na symbolickém kapitálu, jenž každý člen skupiny vlastní coby jedinec“. Cena titulu jedince tudíž stoupá s úspěchy jeho spolužáků a ostatních absolventů. Studovaná škola je si tohoto procesu vědoma, pročež zástupci vedení opakovaně hovořili o potřebě budovat dobré jméno školy - za situace, kdy je pole s MBA programy přesyceno a hodnota samotného MBA titulu eroduje - prostřednictvím úspěšných absolventů (terénní poznámky ze schůze vedení, červen 2012; rozhovor, srpen 2012). Za účelem jejich setkávání založila spolek absolventů, $v$ jehož rámci pořádá různé semináře i méně formální akce.

\subsection{MBA studium a budování sociálního kapitálu}

Jak škola, tak i studující, hovoří o studiu MBA také v pojmech prostředku získávání sociálního kapitálu, tedy kapitálu plynoucího ze zapojení jedince do vztahových sítí, které mají moc zvyšovat jeho osobní prestiž (srov. Bourdieu, 1998). Na svých webových stránkách a v materiálech pro potenciální zájemce škola explicitně zmiňuje mezi nejdůležitějšími přínosy studia získávání nových obchodních kontaktů i přátel z podnikatelských a manažerských skupin, tedy zasítování v „kruhu mocných“. Vyzdvihuje se zde role „skutečně aktivní účasti“ ve výuce. Tu, s otevřeným odkazem na její užitečnost z hlediska budování patřičné sociální sítě, zdůraznil i vyučující na jedné z hodin, jichž jsem se měla možnost zúčastnit (terénní deník, únor 2012). Jiný vyučující zmínil, když v rozhovoru srovnával program MBA s jiným (výrazně levnějším) studijním programem školy, že hlavní rozdíl není v předávaných vědomostech, ale ve spolužácích. Za výraznou výhodu studia MBA označil právě to, že vzhledem k jeho značné ceně získávají studující možnost sítovat se s vysoce postavenými a dobře situovanými lidmi (rozhovor, květen 2012). 
Tohoto rozměru studia jsou si samozřejmě velmi dobře vědomi i samotní studující. Při obědě s jednou studijní skupinou mi bylo např́íklad řečeno, že získávání kontaktů je důvodem, proč do školy chodit, i když za to z hlediska obsahu některé hodiny zcela nestojí. Jeden studující reflektoval tuto situaci velmi explicitně. Jak zmínil, u tohoto typu studia panuje značný cenový rozptyl, přičemž volba konkrétní školy nezávisí jen na hodnocení poměru kvality a ceny, ale je také záležitostí referenční skupiny, do níž se chce člověk v průběhu studia socializovat (terénní deník, únor 2012). Symbolický rozměr výše školného je ostatně, jak již bylo uvedeno, zvažován i samotným vedením školy v momentech nastavování výše školného (rozhovor s vedoucím pracovníkem, listopad 2011). Považuje-li Bourdieu $(1996,1998)$ za podstatnou vlastnost sociálního kapitálu jeho proměnitelnost v jiné, př́iběh zmiňovaného studenta ilustruje, jak se ekonomický kapitál vložený do studia konvertuje v sociální, který pak dále posiluje ekonomický: na základě jeho slov se mu investice do studia vrátily skrze zvýšené př́imy z podnikání díky nabytým kontaktům během několika prvních měsíců (terénní deník, únor 2012).

Rozvíjení sociálního kapitálu coby důležité dimenze MBA programů si všímají také Brocklehurst et al. (2007, s. 380) či Vaara a Faÿ (2011, s. 31). Sturdy et al. (2006, s. 852) pak zmiňují, že v jimi realizovaném výzkumu zdůrazňovali dotazovaní častěji než získané vědění či dovednosti právě přínosy MBA studia v podobě sociálních vazeb. Hall (2011, s. 130), která zkoumala proces utváření sítí mezi absolventy MBA v oblasti finančních služeb v Londýně a jejich mobilizace při utváření kariér, poukazuje na translokální dosahy těchto sítí umožněné rozvojem komunikačních technologií.

Přestože je možno na studiem produkované sociální sítě pohlížet - podobně jako Vaara a Faÿ (2011, s. 32) - kriticky, tedy jako na prostředek vytváření exkluzivních a exkludujících „old boy networks”, mým cílem zde není tvrdit, že jediným nebo nejpodstatnějším motivem sítování je kariérní postup, ani že je tento proces nutně zcela vědomý. Studující, at' už osobně, či v referencích poskytovaných na stránkách školy, často zdůrazňovali př́nos setkávání $\mathrm{s}$ patřičně situovanými lidmi $\mathrm{v}$ přenosu znalostí a zkušeností mimo vlastní pole působnosti - tedy též určitou kognitivní dimenzi kontaktů. I z toho důvodu pro ně může být atraktivní setkávací platformou absolventský spolek, který škola vytvořila, $v$ jehož rámci se konají různé přednášky, ale i neformální aktivity. Přestože $v$ našich končinách dosud nejsou běžné absolventské dary školám, je pravděpodobné, že v budoucnu budou z hlediska škol absolventské sociální sítě představovat, podobně jako ukazuje Hall (2011, s. 126) na př́padu Velké Británie a USA, mobilizovatelné zdroje ekonomického 
kapitálu. V současnosti napomáhá mnou studované škole absolventský spolek především utvářet dobré jméno, nebot' veřejně známí či úspěšní absolventi navyšují její symbolický kapitál. Ten je za podmínek absence příspěvků od státu i nezbytnou podmínkou její ekonomické existence.

\section{Závěrem}

Cílem tohoto textu bylo - na pozadí Bourdieuho konceptualizace forem kapitálů diferencujících společenské postavení jedinců a jeho úvah o vzdělávacím systému coby prostoru reprodukce dělby kapitálu - analyzovat některá specifika MBA programů poskytujících terciární manažerské vzdělávání. Ve středu Bourdieuho pozornosti stojí především reprodukce dělby kulturního kapitálu a role vysokých škol ve vytváření symbolického kapitálu. Různě profilované školy také, jak si všímá, přitahují a oceňují studující s relevantně strukturovanými habituálními dispozicemi. MBA programy z tohoto hlediska představují prostředek reprodukce pozic pro ekonomické elity (jakkoli „masifikace“ programů relativizuje do jisté míry jejich výlučnost). Symbolicky posvěcený kulturní kapitál posiluje legitimitu jejich vládnutí. Enormní výše školného pak zaručuje jistou regulaci přístupu „neoprávněným“.

Program MBA, jenž byl předmětem provedeného etnografického výzkumu, si v rámci prezentace své mise klade za cíl podporovat jako kulturní kapitál studujících, tak zprostředkovaně i ekonomický. Rozšiřování kvalitního manažerského vzdělávání je v prezentacích školy explicitně propojeno s důrazem na materiální úspěch a postup na kariérním žebříčku. Také z důvodu akcentace praktických rovin mají MBA programy, jak naznačují i zahraniční diskuze (napřr. Robbins, 1993, s. 156), nesnadnou pozici na poli vzdělávání. Bývá jim vytýkán nedostatek „vědeckosti“, pročež se relativizuje jejich hodnota coby poskytovatelů kulturního kapitálu. V prostředí ČR navíc Ministerstvo školství, mládeže a tělovýchovy zatím odmítá MBA tituly nostrifikovat, čímž zároveň odmítá také garanci jejich akademické legitimity. Poskytovatelé mnou studovaného MBA programu se proto snažili redefinovat dané rozložení moci prostřednictvím kritiky tradičních vysokých škol pro jejich přilišnou teoretičnost a pro přehlížení ohledů „reálné praxe“. Rezistovali zároveň vůči přidělené definici MBA programů coby programů profesní kvalifikace.

Právě pro údajně vyvážené propojení teorie a praxe bylo poskytované studium označováno za prostředek mimořádného porozumění realitě (či jejímu patřičnému segmentu). Program zároveň buduje u studujících skrze řadu 
subtilních mechanismů (od atribucí pozic mocných po stravování v nejdražších restauracích) pocity jejich výlučnosti a jejich přináležitosti k ekonomické elitě. Tato symbolická práce, jež nalézá svůj odraz v individuálních identitních procesech (Sturdy et al., 2006, s. 850-852), ústí v odlišnost, přičemž symbolické hranice jsou petrifikovány skrze poskytovaný titul. Ač hodnotu titulu negarantuje v tomto př́padě stát, exkluzivita a „posvěcení práva vládnout" se odvozují od západních konotací titulu a zejména pak postavení skupin, které jím disponují. MBA titul může fungovat, jak naznačují výpovědi některých vyučujících, jako klíc ke vzájemnému spojování jeho nositelů. Z provedeného výzkumu však vyplývá, že prvek sítování, v jehož důsledku se navyšuje sociální kapitál jedinců, je již nedílnou součástí studia. Studující, vyučující i webové stránky školy otevřeně tematizují přínos studia a aktivní účast v něm pro získávání důležitých kontaktů. S obdobnými závěry přicházejí i další výzkumy (Brocklehurst et al., 2007, s. 380; Vaara \& Faÿ, 2011, s. 31). Ekonomický kapitál, jenž je investován v poplatcích za školné, se tak proměňuje v kulturní, symbolický i sociální, vlivem jejichž součinnosti zpětně narůstá šance na zmnožení kapitálu ekonomického, a tím i reprodukci či posílení výchozích sociálních pozic.

\section{Literatura}

Bernstein, B. (1975). Class, codes, and control. London: Routledge.

Bourdieu, P. (1988). Homo academicus. Stanford: Stanford University Press.

Bourdieu, P. (1996). The state nobility. Elite schools in the field of power. Cambridge: Polity Press. Bourdieu, P. (1998). Teorie jednání. Praha: Karolinum.

Bourdieu, P., \& Passeron, J.-C. (1964). Les héritiers. Les étudiants et la culture. Paris: Éditions de Minuit.

Bourdieu, P., \& Passeron, J.-C. (1990). Reproduction in education, society and culture. London: Sage.

Brocklehurst, M., Sturdy, A., Winstanley, D., \& Driver, M. (2007). Introduction: Whither the MBA? Factions, fault lines and the future. Management Learning, 38(4), 379-388.

Bowles, S., \& Gintis, H. (1976). Schooling in capitalist America. Educational reform and the contradictions of economic life. London: Routledge \& Kegan Paul.

Collins, R. (1979). The credential society. A historical sociology of education and stratification. New York: Academic Press.

Davies, C. A. (2008). Reflexive ethnography: A guide to researching selves and others. London: Routledge.

Dvořáčková, J. (2013). Tak daleko, tak blízko: k vybraným formám propojení mezi soukromými a veřejnými vysokými školami. Aula: revue pro vysokoškolskou a vědní politiku, 21(2), 3-19.

Gray, C. (2002). What are business schools for? On silence and voice in management education. Journal of Management Education, 26(5), 496-512. 
Gobo, G. (2008). Doing ethnography. London: Sage.

Hall, S. (2011). Educational ties, social capital and the translocal (re)production of MBA alumni networks. Global Networks, 11(1), 118-138.

History of the MBA. (22. 6. 2012). Dostupné z http://www.topmba.com/why-mba/history-mbamba-friday-facts

Jarkovská, L., \& Lišková, K. (2008). Genderové aspekty českého školství. Czech Sociological Review, 44(4), 683-701.

Jarkovská, L., Lišková, K., \& Šmídová, I. (2010). S genderem na trh. Rozhodování o dalším vzdělávání patnáctiletých. Praha: Sociologické nakladatelství, Brno: Masarykova univerzita.

Katrňák, T. (2004). Odsouzeni k manuální práci. Vzdělanostní reprodukce v dělnické rodině. Praha: Sociologické nakladatelství.

Locke, R. R., \& Schöne, K. E. (2004). The entrepreneurial shift. Americanization in European hightechnology management education. Cambridge: Cambridge University Press.

Malý, M. (30. 4. 2014). Studium a kvalita programů MBA v ČR. Dostupné z http://www.cambas. cz/aktualne.asp?Id=19

Matějů, P., Straková, J., \& Veselý, A. (Eds.). (2010). Nerovnosti ve vzdělávání. Od měření k řešení. Praha: Sociologické nakladatelství.

Nekorjak, M., Souralová, A., \& Vomastková, K. (2011). Uvíznutí v marginalitě: vzdělávací trh, „romské školy“ a reprodukce sociálně prostorových nerovností. Czech Sociological Review, 47(4), 657-680.

Oakes, J. (1985). Keeping track: How schools structure inequality. New Haven: Yale University Press.

Otevřený dopis České asociace MBA škol. (12. 2. 2013). Dostupné z http://www.cambas.cz/ aktualne.asp?Id=16

Robbins, D. (1993). The practical importance of Bourdieu's analyses of higher education. Studies in Higher Education, 18(2), 151-164.

Shavit, Y., \& Blossfeld, H.-P. (Eds.). (1993). Persistent inequalities: A comparative study of educational attainment in thirteen countries. Boulder Colorado: Westview Press.

Shavit, Y., \& Müller, W. (Eds.). (1998). From school to work: A comparative study of educational qualifications and occupational destinations. Oxford: Clarendon Press.

Simonová, N. (2011). Vzdělanostní nerovnosti v české společnosti: Vývoj od počátku 20. století do současnosti. Praha: Sociologické nakladatelství.

Sinclair, A. (1995). Sex and the MBA. Organization, 2(2), 295-317.

Sturdy, A., Brocklehurst, M., Winstanley, D., \& Littlejohns, M. (2006). Management as a (self) confidence trick - Management ideas, education and identity work. Organization, 13(6), 841-860.

Šmikmátor, J. (13. 3. 2013). MBA je v Británii akademický titul. Ale ne vždy. Hospodářrské noviny, 12-13.

The MBA - Some history. (19.12. 2003). Dostupné z http://www.economist.com/node/2278420

Vaara, E., \& Faÿ, E. (2011). How can a Bourdieusian perspective aid analysis of MBA education? Academy of Management Learning \& Education, 10(1), 27-39.

Veselý, A., \& Matějů, P. (2010). Vzdělávací systémy a reprodukce vzdělanostních nerovností. In P. Matějů, J. Straková, \& A. Veselý (Eds.), Nerovnosti ve vzdělávání. Od měření k řešení (s. 38-89). Praha: Sociologické nakladatelství. 
Wacquant, L. J. D. (1996). Foreword. In P. Bourdieu (Ed.), The state nobility. Elite schools in the field of power (s. ix-xix). Cambridge: Polity Press.

Willis, P. (1977). Learning to labor: How working class kids get working class jobs. New York: Teachers College Press.

\section{Autorka}

Mgr. Jana Dvořáčková, Ph.D., Masarykova univerzita, Fakulta sociálních studií,

Katedra sociologie, Joštova 10, 60200 Brno, e-mail: dvoracko@fss.muni.cz; Univerzita

Pardubice, Filozofická fakulta, Katedra sociálních věd, Studentská 97, 53002 Pardubice

\section{"Knowledge is power": MBA study program in Bourdieu's perspective of capitals}

Abstract: Based on a one-year ethnographic research conducted at the private higher education institution, this empirical study aims to analyse the MBA study program from the perspective of reproduction of social differences. The first part of the article presents the theoretical background of the study, Pierre Bourdieu's concepts of cultural, economic, symbolic and social capital and his perspective on educational institutions as a means of reproducing social differences. After introducing the basic features of the school under the study, the third, analytical part describes the manifest aims of the program that consist in reinforcement of cultural and economic capital. Besides these goals to provide students with knowledge for promoting their career opportunities and business success, the mechanisms builing of students' symbolic and social capital are depicted. As the text shows, besides its manifest aims, the MBA program functions as a space for the conversion of economic capital into symbolic and social capital. Both of which then increase economic capital and thus enable to reproduce and reinforce students' social positions.

Keywords: MBA, Bourdieu, social reproduction, symbolic capital, social capital, economic capital, cultural capital 